\title{
The end of the post-colonial era: The transformation in Israeli media law on the State's 70th anniversary
}

\author{
Amit Schejter
}

Received: 18 July 2021 / Accepted: 28 October 2021 / Published online: 3 January 2022

(C) The Editors of the Journal 2021

\begin{abstract}
Dramatic changes in media law and practice took place on Israel's 70th year of independence: The Press Ordinance was abolished; the Broadcasting Authority (IBA) was replaced by the Israeli Broadcasting Corporation (IBC); and the Second Authority Law (which governs commercial broadcasting) was amended, abolishing the "dual broadcasting model" established in the 1990s. What characterizes these changes is that they mark the breaking up of Israel's media policy structure from its post-colonial roots. The new laws demonstrate for the first time in Israeli media policy history a unique Israeli structure.
\end{abstract}

Keywords Israel $\cdot$ Post-colonialism $\cdot$ Media law

\section{Introduction}

How long does a post-colonial era last, and how long can media policies developed by an independent state whose foundations were in a colonial system be seen as emanating from the colonial rule? Founded in 1948 following the withdrawal of British forces, Israel is such a case in point. For 70 years it not only maintained legal structures created by the British Mandate, but it also erected two new institutions, a public broadcaster and commercial broadcasting 17 and 32 years after independence, respectively, that were founded with specific reference to the United Kingdom (UK) in their formative documents, and designed resembling their UK counterparts. Both the colonial and post-colonial regimes were dismantled only surrounding the State's 70th anniversary. It is the how and why of this singular phenomenon that is the topic of this study.

Prof. Dr. Amit Schejter $(\bowtie)$

Department of Communication Studies, Ben-Gurion University of the Negev, Beer

Sheva 84105, Israel

E-Mail: amitsch@bgu.ac.il 
Whether Israel can be defined as a post-colonial entity with all of the ideological baggage, mostly negative, such a demarcation brings with it has been an issue of scholarly debate, which has intensified since the 1980s (cf. Penslar 2001). The historical-political-ideological debate notwithstanding, from a mere chronological standpoint, Israel was carved out of a British colony-Palestine-at the end of the UK's colonial rule. At the same time, states designated as post-colonial are characterized by the rule of the indigenous population (cf. Amin-Khan 2012), while Israel, designated by the November 1947 United Nations (UN) resolution to be the "Jewish State," unlike the "Arab State," that was to be formed at the same time next to it but never was, is in fact a predominantly immigrant state.

This definitional challenge aside, a distinct characteristic of post-colonial entities, as promoted by post-colonial scholarship, is their ongoing dependence on the colonial power that had previously ruled the area. The insinuation of this theoretical standpoint has been that the colonial power's impact had continued into the post-colonial era in a way that had distorted power relations in the independent regime, frustrating the efforts to develop a true independent identity (cf. Darwin 1999). Indeed, as Shohat (1992) denotes, the term "post-colonialism" is a misnomer suggesting that the colonial period ended when the colonial forces left the colony as it gained independence; however, colonial influence, which brings with it different forms of cultural domination, may still endure.

This clearly was not the case with UK-Israel relations. Israel was never part of the British Commonwealth, it stripped English from the official language status it enjoyed in the colonial years almost on day one of independence, and after a rocky start of the relationship between the former colonizer and the Jewish State (cf. Aridan 2004), it favored aligning with the United States (US) over forming an alliance with the UK (cf. Levey 1997). The first official visit of a British Premier took place only in 1986 (cf. Friedman 1986) and the first member of the Royal family made an official visit to Israel only in $2018^{1}$ (cf. Kershner 2018).

This study demonstrates therefore the above-mentioned unique aspect of the British-Israeli relationship. It focuses on the changes in Israeli media law and policy that took place as the State turned 70. It claims that the printed press, public broadcasting and commercial broadcasting regulation in Israel were either British colonial legislation (the press) or British-inspired regulatory frameworks (public and commercial broadcasting) until 2017/18. It describes briefly the British structure that served as their inspiration, but mostly, using citations from legal documentation, in particular laws, drafts of laws, and minutes of Knesset discussions, it demonstrates how the British model influenced the Israeli one. It claims that the Israeli media system between 1948 and 2018 was designed by taking on characteristics either left behind by the colonial regime or created in its image in the post-colonial era.

The paper then turns to describe the recent developments that had taken place in 2017 and 2018. It identifies these changes as a declaration of independence from the influence, as well as from the legal legacy, of the British Mandate, coming 70 years after the original declaration of independence was read by David Ben-Gurion in Tel

\footnotetext{
1 Prince Charles had attended the funeral of Prime Minister Yitzhak Rabin following his assassination in 1995, however, that was not considered an official visit.
} 
Aviv, as the British High Commissioner was folding the Union Jack and boarding a ship in Haifa ending 31 years of British rule of Palestine. While the old structure served a self-image of Israel as a British style democracy, the new structure that emerged serves the contemporary Israeli power structure. The paper ends by asking why it took 70 years for this transition, why it took place concomitantly in the print and broadcast media and what implications for the study of post-colonial media systems this transition can offer.

\section{The Israeli media landscape}

For a relatively small country with a language spoken almost exclusively by its inhabitants, the Israeli media landscape is impressively lively and diverse. Upon its foundation in 1948, when the Hebrew speaking community consisted of only 600,000 people, there were 13 dailies in Hebrew, two in German and one in English already in circulation (cf. Naor 1998). An additional newspaper in Arabic, serving the then population of approximately 150,000 Palestinian-Arabs, soon renewed its pre-State publication (cf. Masalha 2009). Over the years, as the country grew to its current population size of 9.4 million inhabitants, of which Jews consist of $74 \%$ and Palestinian-Arabs approximately $21 \%$, the composition of the printed press has changed significantly: National mostly party-owned press (cf. Nossek and Limor 2001 , p. 13), which included a network of dailies in different languages serving immigrant communities, dominated the market until, following the first transition of power from the social-democrat Labor bloc to the conservative-nationalist Likud in 1977 and with the launch of commercial television in the early 1990s, the market became dominated by commercial media.

The small and highly concentrated commercial press market that emerged was dominated between the 1980s and early 2010s by the Yediot Aharonot group (cf. Schejter and Yemini 2016, p. 951). Since 2021, however, the general daily market is split between Yediot Aharonot and Israel Hayom, a freebie funded by a US-based billionaire in order to serve the political interests of Benjamin Netanyahu, who served as prime minister between 2009-2021. A dozen of smaller outlets, which include one broadsheet (Haaretz), another freebie (Maariv), two English papers (Haaretz and Jerusalem Post), two economic dailies (Globes and Calacalist) and mostly religious party papers, share the rest of the market. It is important to note that there is no tabloid culture in Israel (cf. Koren 1998, p. 194). The Covid-19 pandemic, which swept Israel as of March 2020, led to a major drop in the exposure to the printed press, due to lengthy lockdowns and stoppage of public transit services. By the summer of 2021, Israel Hayom was able to regain a daily market share of $32.5 \%$ against Yediot's 25.4\%, with no other outlet reaching even $10 \%$ of the audience (cf. Wertheim 2021).

The electronic press consisted only of radio until 1968. In 1965, radio was transferred from government control to the newly formed Israel Broadcasting Authority (IBA), which was also granted supervision of the military radio station, Galey Tzahal. Television, launched in 1968, became part of the IBA offering in 1969. The first commercial television station was established in 1993; regional commercial radio 
stations joined in the mid-1990s and by 2018, there were 16 of them. A second television channel was launched in 2002 and while there were some changes in the television market composition, which led to the appearance of a third channel in 2018, following mergers the number has remained two-the more popular Keshet 12 and its competitor Reshet13. The number of television viewers that switched from the public monopoly to its commercial competitors as well as the speed in which this transition took place in the 1990s was overwhelming. By 1998, the share of the commercial channel was $62.5 \%$ of the audience and by 2013 the two commercial television stations were viewed by nearly $90 \%$ of the audience (cf. Schejter and Yemini 2016, p. 960).

However, the monopoly over national radio broadcasting maintained by the IBA and its successor, the IBC, has kept its audience share high and by 2021, the joint market share of the public and military stations was over $75 \%$, led by Galey Tzahal's music station Galgalatz, IBC's and Galey Tzahal's news and current affairs networks, and the IBC's music station. The rest of the market is served by the regional commercial stations and commercial "thematic" stations serving the Palestinian-Arab and religious-Jewish communities (cf. Ice 2021).

Cable television was launched in 1989 and direct-to-home satellite in 2000. Since 2015 , both these multichannel platforms are seeing fierce competition from a growing number of over-the-top internet television services, both local and international. In 2013, the market was divided between the cable operator Hot $(57.3 \%)$ and the satellite operator Yes (33.4\%), with a small share (9.3\%) viewing only over-the-air channels (cf. Schejter and Yemini 2016, p. 961); by 2021, Hot's share dropped to $42 \%$, Yes stabilized on $31 \%$, and the rest of the multi-channel market was shared between the OTT operators Cellcom (14\%) and Partner (13\%) (cf. Bergman 2021).

Indeed, the decline in newspaper, television, radio and traditional cable television consumption has given way to a rise in the centrality of online news viewership. The Yediot Aharonot group dominates this market with its Ynet website and mobile application, which is the most popular among local services. It is followed by Mako/N12, which is owned and operated by the leading television network Keshet 12. Other leading online news operators include Walla, whose owner in the mid-2010s has been implicated in bribery cases involving prime minister Netanyahu, and Haaretz. and Maariv, which are online versions of longstanding newspapers enjoying small market shares in both markets. Interestingly, Israel Hayom, by far the most read print newspaper, is not among the leading 20 websites in Israel (cf. Adar 2021).

\section{The Press Ordinance}

British law remained a central backbone of the Israeli system upon independence. The first legislative act made by the provisional council of the newly formed State, the Law and Administration Ordinance 5708 - 1948, stated that the law that existed in the "Land of Israel" (the Hebrew term for Palestine) on May 14, 1948, Independence Day, will stay intact. Article 11 of the act conditions the validity of such laws on the lack of conflict with the laws the provisional council will legislate and on 
the required adjustments to be made in those laws as a result of the establishment of the State.

As such, a number of media-related laws entered the law books of the newly established State, dealing with such issues as copyright, censorship, cinematography screening licensing, wireless telegraphy and the press. The Press Ordinance of 1933 regulated the licensing of and supervision over newspapers. The Wireless Telegraphy Ordinance of 1937 simply forbade the usage of radio waves for broadcasting, and while it mentioned that broadcasting requires a license, unlike the Press Ordinance, which set a procedure for newspapers to acquire a license, it set no procedure for the acquisition of such a license for broadcasting. As a result, the only broadcaster the new State inherited, was the colonial radio service, the broadcasting service, whose management passed from the colonial forces to the new independent government.

The Press Ordinance was enacted in 1933. It was slightly amended and adjusted during the British Mandate five times, and an additional four times after the establishment of the State. However, its main tenets remained: First and foremost, it set the requirement that any publication falling under the definition of a "newspaper" in the country required a license (article 4). It then set detailed information that whoever wishes to publish a newspaper needs to provide the government with the name, age, address, and citizenship of the publisher and the editor, as well as the frequency and language in which the newspaper will be published and the "subjects that it will discuss" (article 5). The Ordinance stipulated the editor's age and education (article 5) and detailed procedures for transitions in editorship (article 16), and the need to ensure ongoing publication or risk losing the license (article 6).

The most well-known of the Ordinance's authoritarian edicts was article 19, which gave the minister of the interior the power to stop the publication of the newspaper for a designated period, if the newspaper published content that may endanger the public's welfare or if it published a false story or false rumor that may elicit panic or despair. In 1953, the Israeli Supreme Court ruled in its landmark Kol Ha' am decision (H.C. 73/53, Kol Ha' am v. Minister of the Interior, 7 P.D. 871) that freedom of speech was inherent to the Israeli legal system, and as a result limited the scope of article 19 to cases in which a "clear and present danger" to the public could have resulted from the false publication. In the decision, the Court cites both British and US scholars in its analysis interchangeably as the inspiration for its decision, as no law that existed at the time stated freedom of expression or of the press as a norm of the State. However, the Supreme Court's determination was never challenged.

\section{Public service broadcasting}

It took 17 years into independence for the first original piece of media legislation to be enacted in Israel. In 1965, the administration of radio, which was then still the sole electronic medium ${ }^{2}$, was transferred from the government to the IBA, a newly established public non-governmental authority.

\footnotetext{
2 The exception being experimental television broadcasts under the auspices of the Instructional Television Trust.
} 
The IBA was created by the Broadcasting Authority Law and was the sole broadcaster of both radio and television (officially launched in 1968) until the second half of the 1980s. Indeed, in the UK as well, public broadcasting was the sole choice for the public for the first 30 years of broadcasting, as commercial broadcasting was introduced in 1956, following the establishment of the Independent Television Authority in 1954 (cf. Briggs 1979, p. 4; Cave 1996, p. 18). The parallels between the two systems are not an outcome of the length of the period in which the transitions took place, but lies rather in the pattern of the transition.

\subsection{The first reading}

Historical accounts of the reasons for the establishment of the IBA in 1965 have rooted it in the desire of the close circle of Ben-Gurion, who remained a member of the Knesset after his resignation from the premiership in 1963, to weaken his heir as prime minister, Levi Eshkol, by limiting his influence on broadcasting, a power Ben-Gurion enjoyed and exploited when he was in power (cf. Mann 2012, p. 100). Naturally, the legal documentation of the change does not emphasize this motivation. On June 17, 1963, a few days prior to Ben-Gurion's resignation, Justice Minister Dov Yosef presented the Knesset with the first draft of a law prepared by a public committee appointed by Ben-Gurion in 1962, the Avidor committee (Knesset Records, June 17, 1963, p. 2087).

The Avidor committee's first challenge, said Yosef, was to maintain the balance between independence of the new authority and the government's responsibility. "We searched for a solution in the system that was accepted in most Western countries, such as England, the Scandinavian countries and Holland," he stated, "that in addition to giving the broadcasting authorities independence in their day-to-day activities, imposed on the government the ultimate responsibility for their actions" (p. 2088). Clauses that maintained this balance, according to Yosef, were the articles that gave the prime minister the authority to set regulations for operating the Authority, to block any action of the Authority at the request of a minority of its executive committee's members, and to void the Authority's powers for a limited amount of time for security or emergency reasons. He then added:

In the discussions we had in the Knesset on the "Voice of Israel" in the past, the critics repeatedly brought up the example of the British broadcasting service as a service that is not dependent on the government, whose example we should follow ...

Yosef then read two clauses from the Royal Charter of the BBC and added:

The minister responsible of the broadcasting service in England, the postmaster general, has the right to veto any broadcast or type of broadcast, and on the other hand the British Broadcasting Corporation is obligated to broadcast any message of any governmental department it is asked to broadcast. They say that these powers of the British government have rarely been used. But it is clear they were maintained in the law. We hope that by us as well ... (p. 2088). 
Note that Yosef is using the British example to invoke rules that maintain the government's power over what supposedly is to be an independent entity.

It should also be noted that Yosef's reliance on the British model is both explicit and implicit. In addition to the direct quote from the Royal Charter, and in relation to the broadcasts of light programming and advertising, he adds: "No one is disputing, I believe, that a broadcasting service has to find a way to all members of society. And that its role is not only to educate and teach, but also to entertain" (p. 2088). Indeed, Yosef is alluding to the BBC's memorable credo, attributed to its founding executive director John Reith, to "inform, educate and entertain" (Humphreys 2009, p. 203).

As interesting is the fact that 17 years after the end of colonial rule, the next to invoke the UK as an ideal to follow, is MK Esther Raziel-Naor, a member of the opposition right wing Herut party, herself a former member of the Irgun, the underground organization who fought the British rule tooth and nail. Raziel-Naor, who was a broadcaster on the underground radio station in the 1930s and whose brother David Raziel was the commander of the $\operatorname{Irgun}^{3}$, did not shy away from seeing the British law as the example to be followed, while criticizing the government's insinuation that maintaining government powers over the public broadcaster is a Britishstyle principle:

English law states how the radio service in England is truly mamlakhti ${ }^{4}$... Well done, but that's still not a promise of an act that denies the broadcasting service from the power of the government, which may seek to exploit it for its own purposes at will (Knesset Records, June 2017, 1963, p. 2089).

She then adds her opposition to commercialization of the Authority. Again, invoking the UK as the inspiration:

While the British broadcasting service acts firmly according to its designation as a public association established not for profit, and that it is not entitled to receive any sponsored programs or programs submitted by others, or ads or commercial advertisements, nothing has been said in this matter in the bill before us (p. 2089)

A fierce opponent of anything British only two decades before, Raziel-Naor does not stop at this. She carries on to complement the British for their concept of public broadcasting:

We know how things are done in the British broadcasting service ... to beat the drum for nothing, there is no need, especially in a country in the position we are, we should not use money and power just in order to beat the ear drums (p. 2090).

\footnotetext{
${ }^{3}$ Raziel was killed in 1941 in Iraq while operating on behalf of the British intelligence. During World War II, the Irgun sided with the British forces in their battle with the Germans.

${ }^{4}$ For a discussion of the term "Mamlakhti," a unique Ben-Gurionist term meaning "non-partisan" and "civic" see: Keidar, N. (2009). Mamlakhtiyut: Ben Gurion's concept of civility. Jerusalem: Ben Zvi Institute [in Hebrew].
} 
In the relatively short debate regarding the law, one more elongated reference to British law and politics was made by MK Shneyor Zalman Abramov of the Liberal Party. Abramov, too, like Raziel-Naor had only praise for the way the British do things. He stated:

As we heard ... the directors of the broadcasting service in England are appointed by the government ... Therefore, why shouldn't we adopt for us the British custom, according to which they are appointed by the government? I am an avid fan of British customs and procedures .... Since we are a young country that cannot wait for generations to create a tradition, we must make laws to ensure here in writing what is ensured in England by tradition (p. 2092).

MK Israel Yeshayahu Sharabi (from the ruling Mapai party) added that "no doubt that we need to learn from the experience of organized nations, and the minister of justice did right as did my predecessor in this debate, in using the example of the English broadcasting service" (p. 2095).

\subsection{The second and third readings}

The second and third reading of the Broadcasting Authority Law focused on the goals of the new authority and did not, as a result, mention the British example much. The exception was again MK Abramov of the Liberal Party. Abramov used the British example to express his opposition to the monopolistic nature of the Broadcasting Authority as well as to the fact that the law creates only a mamlakhti service, which he perceives to mean non-commercial. "Such a thing does not exist in England," he states, "which is the traditional country of the British Broadcasting Corporation. I am not talking about other countries, but about England where for an extended amount of time there was a state monopoly on broadcasting, and over time the monopoly was cancelled" (Knesset Records, March 8, 1965, p. 1454).

While the structural influence on the formation of the IBA was clearly British, the content it carried was more dominantly from the US (cf. Liebes 2000, p. 281). Indeed, while the colonial legacy was British, the cultural colonization by the US cannot be overlooked. Weimann (1984, p. 190) observed that by the 1980s "young Israelis seem to have an idealized perception of "living in America" and that "[h]eavy viewers demonstrate a strong and consistent tendency to overestimate [this idealized worldview], thus painting a rosier picture of reality".

\section{Commercial broadcasting}

US influence was also behind the first attempt to establish commercial television in Israel, which was originated by Liberal and Herut party members (who merged into one party in 1965 and in 1973 formed the Likud). On June 28, 1978, MKs Yitzhak Berman and Roni Milo, both from the Likud, proposed only a modest amendment to the Broadcasting Authority Law. The legal analysis they presented stated that one could assume from the wording of the Broadcasting Authority Law that it provides the Authority with the exclusive right to broadcast (cf. Knesset Records, June 28, 
1978, p. 3300). "This monopoly," reads the explanatory memorandum attached to their bill, "grants an exaggerated power to a small group of people in the design of the views and artistic taste of the Israeli citizenry, without providing a similar opportunity to others to express themselves at will" (p. 3300).

When introducing the proposal on the Knesset floor, MK Berman thought the situation in the US was the one to imitate, listing the UK as a country whose situation was not "ideal," when he stated:

In the United States and to a certain extent in most Western countries there is a natural limit to the power of the effect of any specific television station. ... In Britain there are a number of radio stations, of which half a dozen are privately owned. There are three television channels, of which one or two are operated by private corporations (p. 3272).

However, when the legislative effort to launch a commercial broadcasting service took off, the US influence was all but forgotten.

\subsection{The Kubersky report}

Notwithstanding MKs Berman and Milo's initiative, on July 10, 1978 the ministers of communications and of education and culture, appointed a public committee to "study the issue of a second channel of television in Israel" (Kubersky 1979). The committee, known as the "Kubersky Committee" after its chairman, Haim Kubersky, a public servant, is commonly accepted as the one that laid the groundwork to the establishment of commercial television in Israel.

Surprisingly, one could say even antithetically to the premise of this study, the Kubersky Committee did not see itself at first bound by the British tradition. Appendix A of the Kubersky Report reviews the media systems of four countries: The US, Germany, Holland and the UK (referred to as "England"). However, the reference to these countries may have been but a mere intellectual exercise, as the committee chose the British path to follow and recommended the establishment of a second television channel separate from the Broadcasting Authority and financed by advertising, just like the Independent Television in the UK of the time.

The Kubersky Committee was in search of a model that would balance the desire to have more choice of television channels, yet limit the effect of commercialization, through strict regulatory oversight. This was a very similar dilemma to the one in the UK in the early 1950s when the Independent Television Act was debated in what was "characterized as a battle between those with commercial and ideological interests in the expansion of television services, and those who feared the impact of commercial forces on British cultural life and public service broadcasting" (Johnson and Turnock 2005, p. 16). In the final part of the recommendation section of the Kubersky Report, the committee proposed "possible principles for the independent broadcasting authority law" (p. 30). It wrote that it

... will be characteristic of the separate and independent nature of the second broadcasting authority (similar to the principles to be found in the independent broadcasting authority in England). It is proposed, that the new law will be 
called "the independent broadcasting authority law" (similar to the name of the law in England on this subject) (p. 31).

Still, the committee stressed that the proposed model is only that, a proposition, and that other models are possible as well. However, the only alternative model the committee mentions is "the same way proposed in the report of the Annan committee in England" (p. 31).

The exact history of the legislation on the Second Authority Law is incomplete, due to poor archiving of documents in the 1980s. Still, we were able to draw additional turning points in the process leading to the legislation and to identify the British influence in them. Thus, on July 26, 1983, MK Pinhas Goldstein of the ruling Likud party raised the topic of "an additional channel on television" in the Knesset (Knesset Records, July 26, 1983, p. 3258). He complained that five years have passed since the appointment of the Kubersky Committee and listed additional steps and decisions made that have all led nowhere. The meeting's chairperson, MK Moshe Shahal of the opposition Labor party corrected Goldstein's description of the events stating that "there was in fact a version of the law that was agreed upon by many parts of this house: that the second channel will be designed in the same format of the ITV in England. Afterwards, the issue did not develop because of disagreements whose nature is unknown to me".

\subsection{The first reading}

In 1984 a "national unity" government was formed in light of mass inflation and an elongating war in Lebanon. Representing three quarters of the Knesset, this coalition government could advance issues in the national consensus, such as an economic plan eliminating inflation and a withdrawal of Israeli forces from Lebanon. Among the issues in broad national agreement was the need for a second television channel, and as the legislation was dragging, two Knesset members of the Likud, Pinhas Goldstein and Michael Reiser, proposed in 1985 a private bill for the formation of a "second television network." The government that could not stay behind proposed the "Second Authority for Television and Radio Law," and the debate regarding both was combined (cf. Knesset Records, November 17, 1986, p. 253).

The minister of communications, MK professor Amnon Rubinstein of the small centrist Shinui party, described the process that led to the current moment. He opened the four-hour debate by saying that the Kubersky Report was the guiding light of the legislation ${ }^{5}$ and even though the proposed law does not correspond "in all one hundred percent [to] the Kubersky Committee recommendations; at the end of the day the law and in particular its reliance on the English precedent, were strictly kept by us" (p. 254). "We expanded certain things," he added, "we set a compensation principle $^{6}$ that the Kubersky Committee did not raise, and we are accepting the

\footnotetext{
5 He used the term "a candle to our feet," which does not translate well into English.

${ }^{6}$ It is unclear which compensation principle he is referring to, as there were two in the law: for newspapers and for movie theaters.
} 
principle based on the Kubersky Report as well on the English precedent" (p. 254). He then went on to say:

Why do we have such a national consensus from the Kubersky Committee and up to the draft bill of the joint education and culture and finance committees in this Knesset? ... [because of] the English model ... The English model is considered today, justly, as the best model ... (p. 255).

As the presentation of the law continued, Rubinstein continued to sing the praises of the media system in the UK and to refer to it as his inspiration with regards to ensuring quotas of local production and to the nomination powers of the supervisory council, that remain in the hands of the government. He then added:

I take England as a model. All the bodies that dealt [with the law] did. Gentlemen, in England according to the Broadcasting Act the minister appoints all the members of the council of the IBA ... Had we proposed such a thing, we would have been accused of the destruction of democracy and of raging fascism. [But] this is the situation in England (p. 256).

Indeed, just as in the case of the Broadcasting Authority Law 23 years beforehand, the British model was used in order to strengthen the political influence of the government over what is purportedly an "independent broadcaster."

This last section of the speech provoked MK Yossi Sarid of the Movement for Civil Rights and Peace to call out "are we England?" "No," answered Rubinstein, "we are not England, but you know what? The broadcasting authorities are also not England. When the British government decided to establish the ITV, the IBA-I happened to be there as a young student-the BBC accompanied this with continuous news, with objective reporting and did not go out to war against the government decision."

"We took from England the general idea," Rubinstein explained the franchising system of the new channel before presenting why it was different from the British model and in what ways. He did the same when he explained why, unlike in England, the law he proposes promises newspapers compensation for their loss of advertising when the new channel would launch.

Indeed, the British example was also a source for much skepticism. MK Matityahu Peled of the Progressive List for Peace was one of the opposers of the law. "...we probably are not able to successfully copy British examples, that are to a large extent based on unwritten understandings, on large measures of restraint capacity, things that we do not excel in," he said. "That is why the referral the minister made of our attention to the resemblance between the draft law and between what goes on in England, I for one was not convinced to believe that indeed we have the power to erect something similar" (p. 272).

Peled was not the only skeptic. MK Ora Namir of the Labor party sounded a similar tune. "The people are a little different," she said,

the norms are different, and also when the government appoints, and it appoints politically, because it is a political government, they don't have what we have, in all the parties - first of all the political partisan consideration, and only then the Mamalakhti consideration (p. 276). 
MK Sarid, speaking after her, added:

do me a favor, when in all other things we will look like, even in one thing, England, from the aspect of the solidity of democracy, from the aspect of its roots, from the aspect of its tradition, way of life and the way it holds itself, then I will lean on or hang to tall trees (p. 279-280).

In the second and third readings, on January 30, 1990, no reference was made to the question of foreign impact on the law.

\section{The dismantling of the British mandate}

As Israel entered its seventieth year, in May 2017, Israeli media law underwent major transformations. Indeed, each one of these dramatic changes - the elimination of the Press Ordinance, the liquidation of the Broadcasting Authority and its replacement with the Israel Broadcasting Corporation, and the bifurcation and deregulation of the commercial television regulatory framework-had one characteristic it shared with the other two: it meant the final dismantling of the influence of the British Mandate on Israeli media law. The colony has gained independence.

\subsection{Eliminating the Press Ordinance}

The mere existence of the Ordinance as a remnant of the colonial regime was a constant thorn in the side of Israel's democratic framework, however little was done to do out with it. Negbi (2011, p. 74-77) summarizes the attempts made over the years to eliminate the Ordinance, beginning with opposition and Herut leader Menachem Begin's scathing criticism in 1952 of government threats to close down his party's newspaper using the Ordinance and concluding by reference to a draft bill that was proposed by a Herut party member, Eliyahu Meridor in 1966, and rejected by the Knesset.

In 2007, the government proposed a comprehensive reform, in which its powers to close down newspapers were to be transferred to a court of law. This reform passed one reading in the Knesset, but was abandoned en route to the second reading with no clear documentation in the Knesset minutes for the reason why. However, in the proposal submitted by the government to eliminate the Ordinance in 2017, which eventually passed, "fierce opposition" to the 2007 bill was cited as the reason for its early demise. The clauses that raised most opposition, according to the 2017 bill, were the proposed arrangements' non-applicability to the Internet, the residual power to shut down newspapers left to the courts, the limitations that were left intact regarding qualifications of editors and publishers, and the circulation disclosure measures it proposed to enforce on large publications.

Indeed, the Press Ordinance left an indelible mark on freedom of the press in Israel. While the government's power to shut down a newspaper was much restrained by the Kol Ha'am decision mentioned above, still the government had used its powers to deny licenses quite extensively. An investigative report in the daily Haaretz in 2016 found that in the previous decade alone 62 such requests were denied, for a va- 
riety of reasons (cf. Dolev 2016). More popular, however, was the usage of another remnant of colonialism, Regulation 94 of the Defense (Emergency) Regulations of 1945, which allowed the Ministry of Defense to close down newspapers without any justification. It was used extensively as a tool against Arab language newspapers (cf. Negbi 2011, p. 74) until eliminated by the Knesset in 2016 when the Supreme Court hinted that it may find that it stands in contradiction to the constitutional right for freedom of occupation, created in the 1990s (cf. Negbi 2016).

However, by 2017 it became the Press Ordinance's time to be eliminated. In the explanatory memorandum to the government bill, the following reasons for this sweeping elimination of the Ordinance were cited: the severe harm the Ordinance imposed on the constitutional freedoms of speech and occupation and

the fact that we are speaking here of an Ordinance from the times of the Mandate, which is archaic, whose arrangements are not suited to the developments that have taken place since its enactment in the field of journalism in particular and communication in general (Proposed Bill for the Annulment of the Press Ordinance 2017 , p. 888).

Indeed, while a score of previous attempts to amend or replace the Ordinance failed, in this instance, shortly after entering its seventieth year, Israel ceased to require licenses from newspapers altogether. The Annulment of the Press Ordinance Law passed unanimously with no reservations and only short comments by the committee chair and one member of the Knesset. Thus, without much fanfare, the printed press in Israel entered a new era. It should be noted, though, that the military censor still has powers over newspapers, including shutting them down, emanating from regulation 100 of the Defense (Emergency) Regulations of 1945, yet another remnant of the colonial regime.

\subsection{Public broadcasting}

The Broadcasting Authority had long been an eyesore for Benjamin Netanyahu who has served as prime minister between 1996-1999 and then again between 2009-2021. In his first run for the premiership in 1996 he promised to have it privatized. Upon his election he appointed a committee to make such a recommendation (the Zuckerman Committee), however, the committee failed to do so and its report actually recommended the strengthening of the Authority and was thus disregarded. When Netanyahu became finance minister in 2003, he worked hard to weaken the IBA, this time by lowering the license fee dramatically. However, by the time he was elected prime minister for the third time, in 2013, his newly appointed minister of communications, Gilad Erdan, had more far-reaching plans-eliminating the IBA altogether.

In September 2013, Erdan appointed a committee headed by Ram Landes, a television producer and former commercial television executive, with no previous experience in either government or public broadcasting. The committee handed Erdan in March 2014 a report the main recommendation of which was the closing down of the IBA and the establishment of a new broadcaster in its place (cf. Landes 2014). The most dramatic measure it proposed was the elimination of the license fee. Landes 
handed Erdan and finance minister Yair Lapid the report while standing in front of a sign reading "The television license fee is eliminated as of 31.3.2015." One thing that stands out in the Landes Report is that no comparative work to other countries was done to justify the new policy. Needless to say, the UK was not mentioned.

Notwithstanding the populist roots of the measure, the Knesset went about and passed the new public broadcasting law on July 29, 2014. The new law looked like no British (or other) public broadcasting law known to date and the move was an original Israeli structure. The new corporation is government funded through a levy set on car owners by the ministry of transportation and the members of its institutions, while formally appointed by the government, are picked by a professional panel headed by a judge. It took almost three more years, until May 15, 2017, the day Israel entered its seventieth year, for the new broadcaster to commence broadcasting, as Netanyahu regretted the move, which meant less government control of public broadcasting, and tried to convince his coalition partners to backtrack and resurrect the tightly controlled Broadcasting Authority. Thus, entering its seventieth year, Israel eliminated one of the pillars of the British model of media that had characterized it for more than 50 years.

\subsection{Commercial broadcasting}

On February 7, 2011, the Knesset passed amendment no. 33 to the Second Authority Law of 1990. The amendment revolutionized the regulation of commercial television in Israel by eliminating the franchise regime established in 1990 and replacing it with a "licensing" regime, accompanied by a "light touch" form of regulation. The explanatory memorandum of the bill stated that "the proposed law presents a change in the regulatory system of commercial broadcasting."

Practically, the new amendment meant that channel 2, the first "British" child of the original regulation, designed after the British ITV, was shut down and replaced by two channels run by channel 2's original franchise holders. As a result, there would be three commercial channels licensed, as in 2002 a second commercial channel ("channel 10") was launched. After a number of delays, the new structure came into force in November 2017, right in the midst of Israel's 70th year, and the British model of regulation established in 1990 ceased to exist.

However, the Knesset did not stop at this point. On February 19, 2018, as the celebratory year was ending, and the 70th Independence Day was looming, the Knesset passed amendment no. 44 to the Second Authority Law. This amendment put the final end to the original commercial television regime devised in the $1980 \mathrm{~s}$. The basis for this law, as stated in the official explanatory memorandum ${ }^{7}$, was to deregulate the rules pertaining to a specific genre of cable channels known as "designated channels." The regulatory framework for "designated channels" was established in the 1990s, and they were to serve as cable channels with specific communities or narrow interests guiding their content. Over the years, a channel

\footnotetext{
7 There was a complex political motivation for this law, which is beyond the scope of this study and the methodology it uses to analyze and learn from legal documents. For further information see: http://www. israelnationalnews.com/News/News.aspx/239954.
} 
serving Russian immigrants (channel 9), one serving the Arab-Israeli community (channel 30), and one purportedly designed to serve religious Jews (channel 20) were formed, alongside an MTV style music channel (channel 24). These channels were allowed to carry advertising, were limited to serving the interest or community they were established for, and in return were not subject to the public service content obligations that the broadcast commercial channels adhering to the (UK inspired) public service model were required to follow.

The outcome of the amendment was that these cable channels were moved from the jurisdiction of the Cable and Satellite Council to that of the Second Authority. In order to do so, the whole regulatory mandate of the Second Authority was abolished and the content obligations it was required to take into consideration in its licensing and supervisory roles were minimized to virtually none beyond the power to oversee ethical issues. In addition, strict ownership regulations were lifted, allowing individuals and foreign entities to own up to $74 \%$ of a commercial channel. In the Knesset debate leading to the enactment of this amendment, no foreign example, let alone the UK, was used as an explanation for the logic of this dramatic turn (cf. Knesset Records 19-21/2/2018). Indeed, the final nail had been set in the coffin of the British influence on media regulation in Israel.

\section{Putting post into a post-colonial media regime}

Following the dramatic changes in media law and practice that took place in Israel's 70th year of independence, Israel has, for the first time since independence, "adopted" its own unique media system model, breaking the "chains" of colonial thought and post-colonial influence: The printed press required no licensing; public broadcasting was not funded anymore by a license fee, however, the government was kept within arm's length of appointing its institutions and director general; and commercial television was relieved of all public service obligations.

Indeed, the Israeli media scene was designed with institutions resembling those of the colonial system from which it emerged. Such a structure characterized most postcolonial nations, as described by Katz and Weddel's (1977) comprehensive study of 91 post-colonial countries (which did not include Israel). In addition, legislation curbing freedom of the press intended to serve the colonial military rule was kept in place. This structure, some of which was erected decades after independence, was kept intact, even when changes swept the UK's media system over those 70 years. Even the fact that media content, in particular television, took on a more USoriented form, even though the US model was presented at certain turning points in the process as an option, and despite the fact that Israel had found in the US a closer ally than the UK as the years went by, did not change this pattern.

Post-colonial scholarship is mostly concerned with "the global/imperial context that shaped complex iterations of power as invisible, intangible and yet palpable forces that one can perceive but not fully name" (Kumar and Parameswaran 2018, p. 349). However, when it comes to the case of Israel, it is hard to connect these legal arrangements with a desire to maintain a colonial power structure. In fact, those regulations that were mentioned in the legislative debates as being inspired by 
the UK were all regulations that maintained some government power over public entities, which were to become independent of such influence.

The emerging contemporary structure of the Israeli media map demonstrates less government control of newspapers and electronic media, at least de jure. The addition of new media outlets weakens existing players and potentially diversifies the landscape, yet proliferation of deregulated commercial entities and multichannel providers may lead to further commercialization, trivialization and superficialization of content, as well as to the dominance of individual and foreign owners.

This new landscape does not seem to be the afterthought of a planned strategy. It rather reflects a deeper change in public values. Indeed, Israel's transition from a "developmental state to a competition state" (Levi-Faur 2000), its departure from a developing country to becoming a post-industrial economy, without an intermittent period of stabilization (Sharkansky 1987, p. 5), and the "change from a socialist inspired mixed, highly centralized, highly planned state-centered, protectionist economy to a much more decentralized and international oriented neo liberal one" (Aronoff 2001, p. 447) has been identified and documented two decades ago. The central role telecommunications have had in that changeover has also been a subject of study and comment (cf. Schejter 2006, p. 14).

However, the fields of content regulation maintained the traditional roots described herein: print media was kept under rules deep-seated in colonial law and broadcast media were designed by a post-colonial adaptation of the former colonial power's regulatory model, as was common in most post-colonial entities (Katz and Weddell 1977). The transition taking place around the 70th anniversary of the State adopted a virtual freedom of regulation for the printed press (albeit the military censorship is still intact), a public broadcaster who gets funding directly from government coffers but whose officials and institutions are independent of government supervision, and a commercial broadcasting regulator bereft of the power to consider public service considerations when overseeing content, while overseeing broadcasters stripped of obligations to a bare minimum. This transition was not a direct result of the turn to neoliberalism, nor can it be explained by that turn.

A close scrutiny of Israeli society through its lawmakers and civil society entities will now be required to see if and to what effect this neo-liberal turn is affecting it and to ensure some measure of service to the public interest is maintained.

\section{References}

Adar, C. (2021). Ranking of the leading websites in Israel: Has Mako passed Ynet? https://www.ice.co.il/ research/news/article/822537 (Created 8 June 2021). Accessed 30 Sept 2021.

Amin-Khan, T. (2012). The post-colonial state in the era of capitalist globalization: Historical, political and theoretical approaches to state formation. New York: Routledge.

Aridan, N. (2004). Britiain, Israel and Anglo-Jewry (pp. 1949-1957). London: Routledge.

Aronoff, M. (2001). Radical change in Israel: A review essay. Political Science Quarterly, 116(3), 447-453.

Bergman, R. (2021). Multichannel battle: On the road to a bang in the television market. https://www. calcalist.co.il/shopping/article/s1n40rrlf (Created 15 Aug 2021). Accessed 30 Sept 2021.

Briggs, A. (1979). Sound and vision. The history of broadcasting in the United Kingdom, Vol. IV. New York: Oxford University Press.

Cave, M. (1996). Public service broadcasting in the United Kingdom. Journal of Media Economics, 9(1), $17-30$ 
Darwin, J. (1999). What Was the Late Colonial State? Itinerario, 23(3-4), 73-82.

Dolev, D. (2016). The interior ministry denied publication of tens of newspapers in the last decade. Haaretz. https://www.haaretz.co.il/news/education/.premium-1.2822629 (Created 14 Jan 2016). Accessed 15 July 2021. in Hebrew.

Friedman, T. (1986). Thatcher is first British Premier in Israel. The New York Times, Sec. 1. (p. 3). (1986, May 25)

Humphreys, P. (2009). Media freedom and pluralism in the United Kingdom. In A. Czepek, M. Hellwig \& E. Nowak (Eds.), Press freedom in Europe: Concepts and conditions (pp. 197-212). Bristol: Intellect.

Ice (2021). TGI study: Radio is alive and kicking, which station recorded the largest leap? https://www. ice.co.il/research/news/article/826929 (Created 29 July 2021). Accessed 30 Sept 2021.

Johnson, C., \& Turnock, R. (2005). From start up to consolidation: Institutions, regions and regulation over the history of ITV. In C. Johnson \& R. Turnock (Eds.), ITV cultures: Independent television over fifty years (pp. 15-35). Maidenhead: Open University Press.

Katz, E., \& Wedell, G. (1977). Broadcasting in the third world: Promise and performance. Cambridge: Harvard University Press.

Keidar, N. (2009). Mamlakhtiyut: Ben Gurion's concept of civility. Jerusalem: Ben Zvi Institute [in Hebrew].

Kershner, I. (2018). Prince William will go to Israel, in first official visit by a British Royal. The New York Times. https://www.nytimes.com/2018/03/01/world/middleeast/prince-william-israel-visit.html (Created 1 Mar 2018). Accessed 12.2020.

Knesset Records, February 19-21, 2018.

Knesset Records, July 26, 1983.

Knesset Records, July 29, 1986.

Knesset Records, June 17, 1963.

Knesset Records, June 28, 1978.

Knesset Records, March 27, 1986.

Knesset Records, March 8, 1965.

Knesset Records, November 7, 1986.

Koren, Y. (1998). The medium and the message: Publishing and the media in Israel. Israel Affairs, 5(1), 192-197.

Kubersky, H. (1979). Report of the committee clarifying the issue of a second television channel in Israel

Kumar, S., \& Parameswaran, R. (2018). Charting an Itinerary for Postcolonial Communication and Media Studies. Journal of Communication, 68, 347-358.

Landes, R. (2014). Report of the committee studying the outline for future public broadcasting in Israel

Levey, Z. (1997). Israel and the Western powers 1952-1960. Chapel Hill: University of North Carolina Press.

Levi-Faur, D. (2000). Change and continuity in the Israeli political economy: Multi-level analysis of the telecommunications and energy sectors. In G. Shafir \& Y. Peled (Eds.), The new Israel: Peacemaking and liberalization (pp. 161-188). Boulder: Westview Press.

Liebes, T. (2000). Performing a dream and its dissolution: A social history of broadcasting in Israel. In J. Curran \& M.-J. Park (Eds.), De-Westernizing media studies (pp. 271-287). London: Routledge.

Mann, R. (2012). The leader and the media: David Ben-Gurion and the struggle over Israel's public sphere 1948-1963. Tel Aviv: Am Oved [in Hebrew].

Masalha, O.A. (2009). Arabic press in Israel. https:/www.articles.co.il/article/45469/. Accessed 1 Oct 2021.

Naor, M. (1998). History of the press in Israel: An introduction. Tel Aviv: Miksam. http://lib.cet.ac.il/ pages/item.asp?item=2345. Accessed 1 Oct 2021 [in Hebrew].

Negbi, M. (2011). Freedom of the journalist and freedom of the press. Ra'anana: Open University Press [in Hebrew].

Negbi, M. (2016). We got rid of the Sphinx. The Seventh Eye. https://www.the7eye.org.i1/207453 (Created 16 June 2016). Accessed 15 July 2021.

Nossek, H., \& Limor, Y. (2001). Fifty years in a "marriage of convenience": News media and military censorship in Israel. Communication Law and Policy, 6(1), 1-35.

Penslar, D. (2001). Zionism, colonialism and Postcolonialism. Journal of Israeli History, 20(2-3), 84-98.

Proposed Bill for the Annulment of the Press Ordinance, 5777-2017, H.H. 1115, February 1, 2017

Schejter, A. (2006). Israeli cellular telecommunications policy. Telecommunications Policy, 30(1), 14-28.

Schejter, A., \& Yemini, M. (2016). Media concentration in Israel. In: E. Noam (Ed.), Who Owns the World's Media? Media Concentration and Ownership around the World (pp. 942-984). New York \& Oxford: Oxford University Press 
Sharkansky, I. (1987). The political economy of Israel. New Brunswick: Transaction Books.

Shohat, E. (1992). Notes on the "Post-Colonial". Social Text, 31-32, 99-113.

Weimann, G. (1984). Images of life in America: the impact of American TV in Israel. International Journal of Intercultural Relations, 8, 185-197.

Wertheim, D. (2021). TGI Study: Israel Hayom charging ahead. Current affairs on radio is back big time. https://b.walla.co.il/item/3451054 (Created 29 July 2021). Accessed 9 Oct 2021.

Dr. Amit Schejter is professor of communication studies at Ben-Gurion University of the Negev and visiting professor at Penn State University, currently serving as president of Oranim College. 